\title{
DZIENNIKI KAZIMIERZA GROCHOWSKIEGO I BOGINI GUANYIN. OD REPORTAŻU DO EKSPERTYZY
}

W 1957 r. z powodów rodzinnych i zawodowych postanowiłem rozstać się z pracą w przemyśle. Był to czas, gdy po dojściu Gomułki do władzy zostały nieco złagodzone restrykcje paszportowe i chińska ambasada w Warszawie bez żadnych problemów zaczęła wydawać wizy czasowe do Chin Polakom, którzy urodzili się lub spędzili większość swego życia w Mandżurii. Zamierzaliśmy z żoną pojechać z tej okazji na 3 miesiące do Harbinu, aby odwiedzić jej rodzinę. Od dłuższego czasu chciałem odejść ze stanowiska naczelnego inżyniera w zakładach przemysłowych, aby wykorzystać moją rzadką wówczas w Polsce znajomość języka chińskiego i zatrudnić się w centrali handlu zagranicznego eksportującej maszyny i urządzenia do Chin. Wystąpiliśmy o trzymiesięczną chińską wizę pobytową i bez żadnych trudności ją otrzymaliśmy.

Miałem już wtedy za sobą kilka w miarę udanych prób literackich. Wiosną 1957 r. napisałem dwa opowiadania, które zaniosłem do redakcji prozy Polskiego Radia. Tematem pierwszego z nich, zatytułowanego Tunel, było wysadzenie w końcowym okresie japońskiej okupacji Mandżurii tunelu w górach Wielkiego Chinganu przez polską obsługe pociagu towarowego, który przewoził amunicję dla rozlokowanej w Mandżurii japońskiej Armii Kwantuńskiej. Była to oczywiście fikcja, ale w owych czasach politycznie poprawna. Inna sprawa, że tego typu sabotaże faktycznie na kolei się zdarzały i o udział w jednej z takich akcji byli podejrzani (i odsiedzieli to podejrzenie w japońskim więzieniu) dwaj moi starsi koledzy z gimnazjum - bracia Jan i Stefan Wyrwasowie. Drugie opowiadanie, zatytułowane Złota góra, traktowało o wędrówce międzynarodowej czwórki studentów, poszukiwaczy przygód, przez mandżurską tajgę i przez góry Małego Chinganu. Tam akurat wykorzystałem nieco szerzej wątek autobiograficzny.

Obydwa opowiadania poszły na antenę, a Tunel czytał nawet sam Andrzej Łapicki, co chyba przyczyniło się do powodzenia audycji i nawet otrzymałem kilka listów od słuchaczy. Bardzo wtedy chciałem ten sukces powtórzyć. Tym razem postanowiłem zaproponować współpracę młodzieżowemu tygodnikowi „Dookoła Świata". Było to czasopismo mające opinię w miarę niezależnego. Może nie w takim stopniu jak słynne „Po prostu”, ale nie było drętwe, miało pokaźny nakład i chętnie czytała je młodzież. Mieściło się przy ulicy Smolnej i tam skierowałem swoje kroki, 
wracając do hotelu po otrzymaniu wizy. Miałem przygotowany artykuł o korzeniu żeńszeń. Taką krótką, trochę zbeletryzowaną opowieść o tym, jak to kiedyś, będąc krótko studentem szkoły medycznej, bezskutecznie poszukiwałem tego korzenia w mandżurskiej tajdze. Skierowano mnie z tym artykułem do kierownika Działu Zagranicznego, który prowadził sympatyczny redaktor Tomasz Miecik. Był nieco młodszy ode mnie, ja zaś jeszcze czułem się na tyle młody (miałem wówczas 33 lata), że bardziej pociagało mnie pisanie dla młodzieży niż dla dojrzalszych czytelników miesięcznika „Poznaj Świat”, z którym także rozpocząłem współpracę.

W „Dookoła Świata” pracowało kilkunastu etatowych młodych dziennikarzy, ale wiedziałem, że Dział Zagraniczny przyjmował także reportaże z różnych egzotycznych krajów od przygodnych, niezbyt jeszcze licznych w tym czasie podróżników. Uznałem, że mogłem być jednym z nich i się nie pomyliłem. Redaktor Miecik powiedział mi wtedy, że po moim powrocie z Chin, planowanym na koniec maja, zacznie się sezon ogórkowy i będa potrzebowali czegoś sensacyjnego, z akcentami polskimi, może z okresu wojny rosyjsko-japońskiej, w której Polacy, poddani rosyjscy, musieli walczyć po stronie Rosji, albo z lat okupacji Mandżurii przez Japończyków.

Natychmiast przypomniałem sobie o przeglądanej kiedyś polskiej książce współautorstwa inżyniera Kazimierza Grochowskiego, w której jeden z rozdziałów był poświęcony ukrytym w mongolskich stepach skarbom z okresu rewolucji w Rosji, a także o wydrukowanym parę miesięcy wcześniej w „Przekroju” artykule Jerzego Kasprzyckiego. Przebywając na wycieczce w Ułan Bator, uzyskał od starego Mongoła informację o złocie zagarniętym z Chińskiego Banku Państwowego w Urdze przez carskiego generała, dowódcę Azjatyckiej Konnej Dywizji, barona Romana Ungern von Sternberga. W Mandżurii i Mongolii krążyło wiele wersji tej opowieści, a jedną z nich przedstawił Grochowski w książce Polacy na Dalekim W schodzie w oparciu o swoją rozmowę z Tatarem i Mongołem, którzy podawali się za jedynych pozostałych przy życiu uczestników zakopania skarbów ${ }^{1}$. Streszczam ją tu w telegraficznym skrócie.

Baron miał polecić 16 Tatarom i Mongołom, którym ufał, zakopanie skarbu w miejscu położonym $160 \mathrm{~km}$ na północ od Hajłaru. Miejsce ukrycia miało znajdować się na terenie koncesji górniczej inżyniera Grochowskiego w Mongolii (Bardze), kilka lat wcześniej uzyskanej przez niego od miejscowych władz Bargi, które w 1916 r. uniezależniły się na krótko od Chin. Po powstaniu w 1932 r. utworzonego przez Japończyków marionetkowego państwa Mandżukuo koncesja Grochowskiego znalazła się częściowo na jego terenie, częściowo zaś na terytorium utworzonej przez Sowietów i mongolskich rewolucjonistów Mongolskiej Republiki Ludowej. Grochowski zanotował ze słów Mongoła historię pewnego listu Ungerna, napisanego rzekomo tuż przed wykonaniem na nim wyroku śmierci w Nowonikołajewsku. Zgodnie z ta jego relacją adresowany do Niemiec list zawierał nazwisko pewnego Polaka znającego miejsce ukrycia skarbu i trafił do mongolskich lamów, którzy dopiero po roku 1930

1 K. Grochowski, Polacy na Dalekim Wschodzie, Harbin 1928. 
mieli możliwość przekazania go niemieckim inżynierom z firmy AEG, budującym w Urdze (wówczas już stolicy Mongolii Ułan-Bator) pierwszą elektrownię. List ten został wysłany przez nich via Tokio do Niemiec, wcześniej jednak z jego treścią zapoznały się japońskie tajne służby Kempeitai. Kto mógł być tym tajemniczym Polakiem znającym miejsce ukrycia skarbu, Mongoł nie wiedział. Ja też nie, choć nasuwały się nazwiska Grochowskiego, Ferdynanda Antoniego Ossendowskiego i Kamila Giżyckiego. Końcówka wspomnianej relacji Grochowskiego brzmiała:

W odległości mniej więcej $160 \mathrm{~km}$ od tego miasta krajowcy doszli do przekonania, że nie zdołają wykonać polecenia barona, tj. uratować jego kasy. Na naradzie odbytej głęboką noca postanowili złoto ungernowskie zakopać, a sami ratować się ucieczką. W lekko falistej okolicy stepowej, pokrytej rzadkimi krzakami, wyszukano małe wgłębienie gruntu, tutaj wykopano jamę, w której złożono wszystkie 24 skrzynie ze złotem, a oprócz tego jeszcze ciężki, ważący siedem pudów kufer barona, który był pokryty blachą cynkową. Co było w tym kufrze, krajowcy nie wiedzieli i sądzili, że były tam baronowskie papiery. Po tym wszystkim wyruszono natychmiast w dalszą drogę. W odległości kilkunastu kilometrów od wklęsłości, gdzie zakopano złoto, porzucono w rozmaitych miejscach arby [mongolskie dwukołowe wozy - E.K.]. Ale w kilka godzin po wschodzie słońca dognali ich bolszewiccy jeźdźcy. Po krótkiej strzelaninie pozostali przy życiu krajowcy rozproszyli się na wszystkie strony. Tylko dwóch z nich dotarło żywymi do Hajłaru.

Za właściciela tego złota uważa się Bank Chiński, na tej podstawie, że niby to większość złotych monet ma pochodzić z Chińskiego Banku Państwowego w Urdze, który to bank baron Ungern-Sternberg (...) w rzeczywistości obrabował².

Jednym słowem - był to materiał sensacyjny z akcentami polskimi i w sam raz na sezon ogórkowy. Zaproponowałem redaktorowi Miecikowi, że napiszę artykuł o inżynierze Grochowskim, który przez kilka lat przebywał w Mongolii i poszukiwał tych skarbów w stepie na obszarze swojej koncesji, a później był dyrektorem Gimnazjum im. Henryka Sienkiewicza w Harbinie i moim szkolnym nauczycielem. Przy okazji zamierzałem wspomnieć także o innych Polakach znajdujących się w czasie tych mongolskich wydarzeń w otoczeniu barona, m.in. o Antonim Ferdynandzie Ossendowskim i Kamilu Giżyckim. Redaktor Miecik natychmiast propozycję zaakceptował i jednocześnie ją niejako rozwinął. Nie miał to być artykuł na jeden numer, tylko taki serial w kilku odcinkach co najmniej na cały lipiec, na sam środek sezonu ogórkowego. W ten sposób zupełnie dla mnie nieoczekiwanie zostałem, „specjalnym wysłannikiem” „Dookoła Świata” na Daleki Wschód. Nie do Chin, tylko na cały Daleki Wschód, gdyż tereny, na których rozgrywały się wydarzenia z okresu rewolucji w Rosji, obejmowały swoim zasiegiem zarówno Chiny (wraz z dawną Mandżurią i mongolskimi księstwami leżącymi po wojnie już w granicach Chin), jak i wschodnią Syberię, Mongolię Wewnętrzną oraz Zewnętrzną, czyli teraz już niezależną od Chin Mongolską Republikę Ludowa. Tytuł „specjalnego wysłannika”, przynajmniej

2 K. Grochowski, Polacy..., s. 125-127. 
w moim przypadku, był zresztą wysoce umowny. Koszty podróży pokrywałem sam z otrzymanego niedawno honorarium autorskiego za swoja pierwszą wydaną drukiem książęe. „Dookoła Świata” zaopatrzyło mnie natomiast w zaświadczenia, że wysłało mnie na Daleki Wschód w celu zebrania materiałów do reportaży oraz zobowiązało się do wydrukowania tego, co napiszę i zwrócenia mi w ten sposób części kosztów podróży. Przed wyjazdem miałem okazję poznać większość członków kolegium redakcyjnego i wiedziałem dokładnie, o czym i jak miałem pisać.

Powinienem w tym miejscu zaznaczyć, że tematyka dalekowschodnia zaczynała być wówczas modna. W latach 1956 i 1957 „Żołnierz Polski” drukował w odcinkach

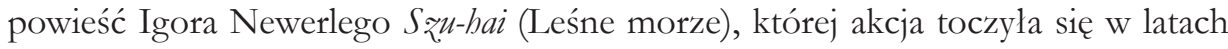
okupacji japońskiej w Mandżurii. Historia ta cieszyła się tak wielkim zainteresowaniem, że gazeta znikała ze sprzedaży już z samego rana. Potem zaś, chyba przez następne 2 lata, była nadawana w odcinkach w Programie Pierwszym Polskiego Radia. Sam śpieszyłem się, aby wrócić z pracy do domu przed rozpoczęciem transmisji i mogę potwierdzić, że faktycznie ulice polskich miast wyludniały się w czasie nadawania tych audycji. Relację Grochowskiego o skarbach Ungerna znałem już wcześniej, gdyż w Harbinie jego książki nie były w polskich domach rzadkością.

Miałem szczęście, że przyjechaliśmy tym razem do Harbinu wczesną wiosna 1958 r., kiedy jeszcze wielu uczestników wydarzeń rewolucyjnych w Rosji, walczących w szeregach białych armii z bolszewikami, nigdzie nie wyjechało. Decyzja Chruszczowa o zezwoleniu na wjazd do ZSRR mandżurskiej „białej emigracji”, a przy okazji złagodzenie także trybu wyjazdów do Australii i innych państw zachodnich spowodowały, że od 1958 do 1960 r. (kiedy po raz kolejny znalazłem się półprywatnie i półsłużbowo w Chinach) większość cudzoziemców wyjechała z Harbinu. Gdybym więc przyjechał później, nie miałbym szans na zebranie tak wielu materiałów do przyszłych książek, które przywiozłem do Polski z tej pierwszej podróży.

Najważniejszą z tych zdobyczy był dziennik uczestnika walk stoczonych z Chińczykami i bolszewikami przez Azjatycką Konną Dywizję Ungerna w Mongolii i na Syberii. Był to niepozorny sześćdziesięciokartkowy zeszyt, zapisany kaligraficznym pismem, z czarną lakierowaną okładką z kaliko. Na naklejonym karteluszku widniał wyblakły tytuł zapisany fioletowym atramentem: Notatki z kampanii barona Ungerna. $\mathrm{Na} 120$ stronach opisano wydarzenia obejmujące niecały rok: od czerwca 1920 do końca maja 1921 r., czyli cały okres od wyruszenia Azjatyckiej Konnej Dywizji z Daurii do Mongolii, zdobycia przez „Dziką Dywizję” Urgi i większości terytorium Mongolii Zewnętrznej, do czasu wyruszenia przeciw bolszewikom do Zabajkala. $\mathrm{Na}$ wewnętrznej stronie okładki zostało puste miejsce po fotografii albo autora relacji, albo jej głównego bohatera. Relację rozpoczynał krótki szkic biograficzny barona Romana Ungerna von Sternberga, kończył zaś jego słynny rozkaz numer 15 z 21 maja 1921 r., wydany według niektórych autorów przy udziale Antoniego Ferdynanda Ossendowskiego. Rozkaz napisany był już innym pismem i innym atramentem. Co zatem mogło stać się z dotychczasowym właścicielem dziennika? 
Czyżby zginął podczas spisku na barona, jaki zawiązali przeciw niemu jego dotychczas lojalni rosyjscy oficerowie?

Wówczas w artykule pt. Bogowie opusz̨æaja wagórz̨a... opisałem okoliczności, w jakich stałem się właścicielem tego niezwykłego dokumentu, dzięki któremu mogłem znaleźć odpowiedź na pytanie od lat nurtujące autorów próbujących ustalić, co w książce Ossendowskiego było prawdą, a co fikcją literacką:

W końcu lat dwudziestych [XX wieku - E.K.] mój ojciec uczestniczył w wyprawie geologicznej [profesora Edwarda Anerta - E.K.] do miejscowości Hsiaolin oddalonej o osiemdziesiąt kilometrów od Charbina [wtedy jeszcze nazwę tego miasta pisano przez „Ch”E.K.]. W pasmach górskich otaczających Hsiaolin znaleziono mangan, ołów i srebro. Niestety wszystkie papiery pozostawione przez ojca zaginęły w czasie przeprowadzek, zanim osiagnąłem dorosłość. Począwszy od 1946 roku, przez długie lata szukałem jakichkolwiek materiałów o wspomnianej ekspedycji. Przeglądnąłem dziesiątki czasopism fachowych z tego okresu, byłem nawet w okolicach Hsiaolinu. Niestety, bez skutku. Gdy w lutym 1951 roku opuszczałem chiński port Qinghuangdao, aby po blisko trzech miesiącach egzotycznej podróży dotrzeć do Gdyni, nie sądziłem, że za kilka lat ponownie ujrzę azjatycki krajobraz, z jego groźnie piękną przyroda, nieprzebytymi pasmami „,sopek", dziewiczą tajgą. Był to okres wojny koreańskiej. Na statku wpadła w moje ręce stara polska książka, własność jednej z repatriantek. Nie mogłem później osoby tej znaleźć w Polsce, jak również nie zapamiętałem ani tytułu, ani autora książki. Pozostała w mojej pamięci tylko okładka. Pamiętałem także, że we wspomnianej książce była jakaś wzmianka o skarbie Ungerna. Będąc ostatnio w Charbinie, postanowiłem ponowić próbę odszukania materiałów o ekspedycji profesora Anerta.

W Chinach od lat istniała specyficzna organizacja skupu wszelkiego rodzaju starzyzny. Rozgałęziona sieć ulicznych handlarzy skupowała po domach używane ubrania, artykuły gospodarstwa domowego, książki. Skupione przedmioty wędrowały o świcie następnego dnia na umówione miejsce, najczęściej ulicę czy plac i tam nabywali je właściciele sklepów, antykwariatów itp. Pewnego mroźnego poranka wsiadłem do tramwaju w kierunku „Piętnastej Ulicy” - miejsca, gdzie godzinę po wschodzie słońca trudno przedrzeć się przez tłum kupujących. Przedmioty rozłożone są wprost na jezdni i jest tego takie mnóstwo, że nie sposób jest w stosunkowo krótkim czasie przebywania handlarzy na ulicy zdążyć obejrzeć wszystko. Większość sprzedawanego towaru pochodziła od Rosjan opuszczających masowo Chiny. Wszędzie na ziemi leżała masa książek, papierów, szkolnych zeszytów. Można tu było znaleźć wszystko - od podręcznika miłości Van der Veldego począwszy, a kończąc na pożółkłym dzienniku uczestnika pochodu barona Ungerna... Tak jest - pamiętnika z pochodu Ungerna.

W wycieczce na bazar charbiński towarzyszył mi antykwariusz G. W drodze powrotnej rozmawialiśmy o ekspedycjach profesora Anerta i o moim niepowodzeniu w poszukiwaniach. G. wspominał o bogactwach naturalnych ukrytych w nieprzebytych wzgórzach Mandżurii i to mi przypomniało odległa rozmowę o skarbach Ungerna. Pół godziny później G. położył przede mną niewielki postrzępiony brulion w czarnej ceratowej okładce, opatrzony wyblakłym od działania słońca i czasu tytułem „Pamiętniki z pochodu barona Ungerna”3.

3 E. Kajdański, Bogowie opuszczaja wagórza, „Dookoła Świata” 1958, nr 240. 
Tu mała dygresja. Na liście odkrytych przez polskiego geologa Edwarda Anerta metali w górach Hsiaolinu pominąłem cynk. Ojciec był wówczas właścicielem niewielkiej fabryki baterii elektrycznych w Harbinie, dokąd przeniósł ją z zajętego przez bolszewików Władywostoku, cynk zaś był jednym z podstawowych surowców niezbędnych do ich produkcji. Był importowany z zagranicy i ojciec miał duże trudności z zapewnieniem ciagłości produkcji baterii elektrycznych poszukiwanych w związku z notorycznymi przerwami w dostawach prądu. Anert zaproponował ojcu spółkę: on brał na siebie zapewnienie dostaw cynku, ojciec miał sprowadzić z Niemiec walcarkę do wyrobu blachy cynkowej. Znalazłem w jego papierach zamoczony (przechowywany $z$ braku miejsca w przeciekającej szopie) niemiecki kata$\log z$ ofertami walcarek. I nic poza tym.

W czarnym brulionie odkryłem natomiast jakże cenny dla mnie szczegółowy opis koronacji w Urdze „żywego boga” - Bogdo Gegena, który miałem teraz możliwość porównać z opisem pozostawionym przez Ossendowskiego w jego książce Zwieržłta, ludzie, bogonie. Nie wiedziałem jeszcze wtedy, że Grochowski znał się z Ossendowskim ani że zapisał w swoich notatnikach znacznie więcej na temat skarbu barona, niż opublikował. Niemniej jednak byłem pewny, że uda mi się odnaleźć w Harbinie osoby pamiętające tamte wydarzenia i będące w stanie coś dopowiedzieć mi zarówno o samym Ungernie, jak i o losach jego urgińskiego złota. Nie pomyliłem się w tych rachubach. W mieście żyło jeszcze wiele osób pamiętających tamte wydarzenia, choć często ich opowieści obfitowały w sprzeczności i wzajemnie się wykluczały. Poznałem paru byłych żołnierzy Ungerna, którzy przeszli z nim cały szlak bojowy od Daurii do Urgi i później przedarli się przez bolszewickie kordony do zbawczej dla nich Mandżurii. Jeden z nich twierdził, że wycofywał się z tym samym oddziałem co Kamil Giżycki. Udało mi się odnaleźć nawet współtowarzysza samego Ossendowskiego w jego podróży fiatem barona z Urgi do Hajłaru. Do dziś nie wiem, czy był autentyczny, czy samozwańczy. Był już wtedy nałogowym alkoholikiem i jego sąsiedzi z harbińskiej dzielnicy biedoty nazywali go „Rudym”.

Tak więc wróciłem do kraju z niemal gotowym już reportażem, odpowiadającym wymaganiom sezonu ogórkowego. Starałem się nadać całej opowieści bardziej sensacyjny charakter, więc na plan pierwszy wysunąłem wątek skarbu, który przewijał się w różnych publikacjach poruszających temat zdobycia przez Ungerna Urgi, zajętej wówczas przez wojska chińskie. Materiał został przyjęty przez redakcję niemal z zachwytem i wydrukowany w czteroodcinkowym cyklu pod wspólnym tytułem Bogowie opuszczaja wagórza... ${ }^{4}$ Postać inżyniera Grochowskiego tworzyła w nim jedynie coś w rodzaju klamry spinającej w jedną całość poszczególne wątki narracji o Ungernie, jego złocie i Ossendowskim.

4 E. Kajdański, Bogowie opusz̨zaja wzgórz̧a, czteroodcinkowy reportaż w „Dookoła Świata” z 1958 r.: odc. 1. Miasto zestańców, nr 240; odc. 2. Dynamit i strychnina, nr 241; odc. 3. Na poludnie od Hajłaru, nr 242; odc. 4. Wyprawa po żłote runo, nr 243. 
Redaktorzy „Dookoła Świata” zadbali o to, aby nad tym cyklem moich reportaży roztoczyć aurę sensacyjności i tajemnicy. Przybyło nieco dialogów, choć ta lekka beletryzacja nie wpłynęła na autentyzm tego, co napisałem. Jednak to, że odniósł on taki sukces czytelniczy, było w dużej mierze ich zasługa. Wiem o tym doskonale, gdyż przekonałem się na własnym doświadczeniu, że bez odpowiedniej formy i bez reklamy najlepszy artykuł czy równie dobra książka nie miały szans na przebicie się do szerszego grona czytelników. Już pierwsza zapowiedź w tytule pierwszego odcinka tworzyła atmosferę jakiejś wielkiej tajemnicy: „Bogowie opuszczają wzgórza...i dalej: „ta odpowiedź, dana przez starca, który znał barona von Ungerna, jest jednocześnie tytułem pasjonującego reportażu rzucającego nowe światło na jedną z dotychczas nierozwiązanych tajemnic dwudziestego wieku". Niżej zaś moje zdjęcie opatrzone następującym podpisem:

Inżynier Edward Kajdański, specjalny wysłannik „Dookoła świata” na Daleki Wschód. Wędrówka autora reportażu „Bogowie opuszczają wzgórza”, która prowadziła szlakiem „dzikiej dywizji”, przyniosła rewelacyjny sukces: odnalezienie oryginalnego pamiętnika „krwawego generała” - barona Ungerna-Sternberga. Wielki reportaż Kajdańskiego jest nie tylko próbą rozwikłania pasjonującej zagadki skarbu barona Ungerna. Nasz wysłannik, jeden z niewielu Polaków znających biegle język chiński, znawca spraw Dalekiego Wschodu, opisuje wiele stron surowego życia ludzi napotkanych na tajemniczym szlaku swej długiej niebezpiecznej wędrówki.

Do tego dołączono na dwustronicowej rozkładówce wielkie zdjęcie, na którym widać było ręce trzymające zapisany zeszyt z zamaszystym podpisem barona. Pod nim zamieszczono informację:

Niewielki postrzępiony brulion w czarnej ceratowej okładce nosi tytuł: „Pamiętniki z pochodu barona Ungerna”. Niecodzienna historia tego zeszytu stanowi pasjonująca zagadkę, którą przynajmniej częściowo wyświetlił nasz specjalny wysłannik.

Przy końcu odcinka dodano natomiast zapowiedź: „W następnym numerze: „Żywy Bóg” w areszcie * Czy istniał skarb? * Tajemnice pamiętnika * Przepowiednia lamów". Dodatkowo redakcja wyjątkowo opatrzyła mój reportaż notką Copyright by „Dookoła Świata”. Wprawdzie nikt się nie zgłosił z propozycja przedruku, ale zawsze to było coś. Jaki magazyn bawiłby się dziś w promowanie nieznanego, choćby nawet obiecującego autora?

Jednym słowem - reklama była w stylu iście amerykańskim i w pewnym konflikcie z prawda, ale skuteczna: wszystkie te przymiotniki: „pasjonujące”, „nierozwiązane”, „tajemnicze”, „niebezpieczne” i inne zrobiły swoje i stałem się przez to „reporterska gwiazdą" jednego sezonu. No, może dwóch. W następnym roku na życzenie redakcji napisałem obszerny świąteczny (wielkanocny) esej: Gdybys ty sỳt $C_{\text {żyngis-chanie }}^{5}$. Jednak

5 E. Kajdański, Gdybyśs ty ṡył Drèngis-chanie, „Dookoła Świata” 1959, nr 273 i 274. 
już w 1960 r. ze względu na sowiecko-chiński spór ideologiczny tematyka chińska znikła ze stron kolorowej prasy, ja zaś podjąłem nową pracę, która zmusiła mnie do zapomnienia na kilka dobrych lat o pisarstwie.

Muszę przyznać, że gdy ostatnio przeglądałem numery „Dookoła Świata”, w których drukowane były moje reportaże, zaskoczyła mnie różnorodność poruszanej w tygodniku tematyki i owa - być może względna - niezależność, jaką miało to młodzieżowe pismo w wyborze materiału do publikacji. Po dojściu do władzy Gomułki czas był nieco szczególny, bo cenzura na łamach tygodnika była zupełnie niezauważalna. Moje publikacje są tego dowodem. Nie były w najmniejszym stopniu ocenzurowane (sprawdziłem!), a przecież pisałem niemal z zachwytem o byłym właścicielu kopalni złota - kapitaliście inżynierze Grochowskim, o śmiertelnym wrogu bolszewików - „białym krwawym baronie Ungernie” i, co nie byłoby możliwe na początku lat pięćdziesiątych ani już kilka lat po październiku, o Ferdynandzie Antonim Ossendowskim i jego zakazanej w PRL od 1951 r. książce Zwieržta, ludzie, bogonie.

W ogóle „Dookoła Świata” było w 1958 r. tygodnikiem niezwykle barwnym (i w przenośni, i dosłownie) oraz ciekawym, bez żadnych śladów drętwoty. $\mathrm{Na}$ większości okładek kolorowe zdjęcia pięknych dziewczyn, przeważnie w strojach kapielowych, bo był środek lata, choć nikt wtedy nie kojarzył tego z przejawami seksizmu. Wprost przeciwnie, uważało się, że „Dookoła Świata” torowało drogę do pluralizmu, przełamywało różne tabu, walcząc z szarością szaty graficznej i drętwotą języka „Trybuny Ludu” oraz innych słusznych tytułów. W tygodniku zamieszczano sporo tłumaczeń z języków obcych, reportaży przedrukowywanych z pism zachodnich, artykułów o tematyce kobiecej, oczywiście z zachodnią modą na czele, itp. Pismo posuwało się nawet do dwuznacznych żartów, jak np. w numerze 243, w rubryce „Dookoła światka”: „magazynek nr. 28, 17 sierpnia 1958, cena - darmo, nakład: zależny od wielki ego brata... telefon (jeżeli nie popsuty) 802-81, wewn. 332...”. Redaktorzy cieszyli się przy każdej okazji, gdy cenzura coś takiego przepuściła lub nie zauważyła.

Przy którejś wizycie w gabinecie redaktora Miecika poznałem Zofię Nasierowską, przyszłą mistrzynię fotoreportażu, przez całe lata ilustrującą większość najpoczytniejszych pism kolorowych. Była wtedy wysłanniczką „Dookoła Świata” do Paryża, chyba na podobnych warunkach jak moje. Jej wielki reportaż Paryżanie ukazał się w tym samym numerze co ostatni odcinek mego reportażu o Ungernie i Ossendowskim i chyba dzięki głodnym wiedzy o zachodniej modzie czytelniczkom mój cykl spotkał się z takim powodzeniem. Numeru „Dookoła Świata”, w którym ukazał się drugi odcinek, już o ósmej rano nie można było kupić w kioskach „Ruchu” (w owym czasie nie było jeszcze trudności z papierem i nie wszystkie nakłady poszczególnych numerów tygodnika udawało się sprzedać). Temat okazał się tak nośny, że otrzymałem ponad sto listów (to był niemalże rekord), nie licząc tych, które były kierowane bezimiennie do redakcji. Były tam sprostowania i uzupełnienia do przedstawionego przebiegu wydarzeń pisane przez byłych polskich oficerów i żołnierzy Ungerna, 
EDWARD KAJDANSKI
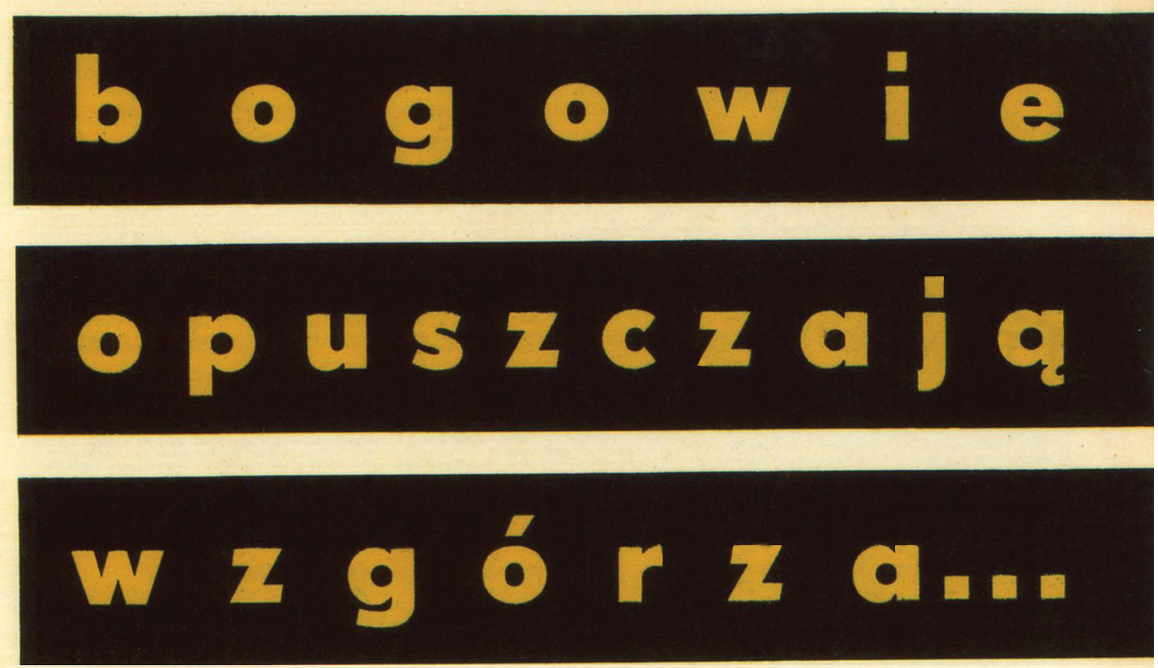

Copyright by "Dookola świata"
...TA ODPOWIEDZ, DANA PRZEZ STARCA, KTORY ZNAL BARONA VON UNGERNA, JEST JEDNOCZESNIE TYTULEM PASJONUJĄCEGO REPORTAZU RZUCAJĄCEGO NOWE SWIATEO NA JEDNA $Z$ DOTYCHCZAS NIEROZWIKEANYCH TAJEMNIC DWUDZIESTEGO WIEKU.

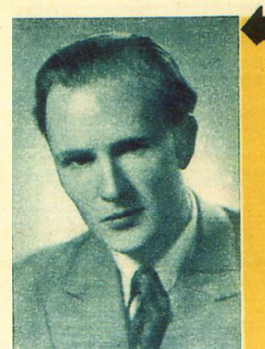

Inżynier Eutward Kajdaniski, specjalny wysłannik „Dookoła świata“ na Daleki Wschód. Weadrówika autora reportażu "Bogowie opuszczają wzyórza", kłóra prowadzila szlakiem "dzikiej dywizji", przyniosła rewelacyjny sukces: odnalezienie oryginalnego pamiętnika "krwawego generala" - barona Ungerna-Sternberga. Wielki reporlaź Kajdahiskiego jest nie tylko próbą rozwiklania pasjonującej zagadki skarbu barona Ungerna. Nasz wystannik, jeden z niewielu Polaków znających hienle język chiński, znawca spraw Dalekiego Wschodu, opisuje wiele stron surowego życia ludzi napotkanych na tajemniezym szlaku swej długiej i niebezpiecznej wędrówki.

Il. 1. Pierwsza strona artykułu E. Kajdańskiego pt. Miasto zesłańców z czasopisma „Dookoła Świata" 1958, nr 240

Źródło: Archiwum E. Kajdańskiego. 
uczestników szturmu Urgi. Były anonimowe propozycje przekazania mi za odpowiednią opłata całej historii Azjatyckiej Konnej Dywizji i osobistych zwierzeń autorów listów. Otrzymałem nawet dwie propozycje wspólnego wyjazdu do Mongolii w celu odkopania zaginionego skarbu.

Co paradoksalnie okazało się potem dla mnie najważniejsze, w tym potoku korespondencji znalazły się listy, które zwróciły moją uwagę na pozostawioną niejako w cieniu skarbowego wątku sprawę podróży inżyniera Grochowskiego po Dalekim Wschodzie i jego dorobku naukowego. Pochodziły przeważnie od byłych mieszkańców Harbinu - repatriantów, którzy wrócili do kraju pierwszym transportem kolejowym. W listach tych znalazłem informacje, że wszystkie materiały Grochowskiego powinny znajdować się w Polsce, gdyż zostały przekazane przez wdowę po nim delegatowi rządu polskiego ds. repatriacji - komandorowi Jerzemu Kłossowskiemu. W jednym z tych listów przeczytałem, że Kłossowski zabrał z sobą także wiele cennych znalezisk Grochowskiego z wykopalisk, jakie prowadził w zasypanych piaskiem ruinach miasta, zwanego przez miejscową ludność Miastem Czyngis-chana. Wśród nich miała znajdować się bardzo cenna figura z brązu przedstawiająca chińską boginię Guanyin w jej chrześcijańskim, nestoriańskim wcieleniu. Nikt z repatriantów interesujących się losem tych przedmiotów nie był w stanie dowiedzieć się, co z nimi w Polsce się stało. W Harbinie było kilka osób, które korespondowały z panią Elżbietą Grochowska, i ktoś z nich dał mi jej adres w Stanach Zjednoczonych. Po przyjeździe do Polski w 1949 r. dzięki pomocy komandora Kłossowskiego miała ona uzyskać zgodę na opuszczenie kraju i wyjechać do syna do San Francisco. Napisałem więc do p. Grochowskiej długi list, w którym wspomniałem o przygotowywaniu reportażu o jej mężu i poprosiłem o parę słów na temat jego spotkań z baronem Ungernem i Ossendowskim. Wiedziałem z otrzymanych listów jedynie to, że Ungern miał go uratować od śmierci, zaś Ossendowskiego poznał osobiście w czasie swego pobytu w Mongolii. Przy okazji zapytałem także p. Grochowską o to, co stało się z dziennikami podróży naukowych jej męża i z przedmiotami z wykopalisk, które w 1949 r. przekazała delegatowi rządu przeprowadzającemu repatriację.

Tak się fortunnie dla mnie złożyło, że w latach 70. XX wieku pracowałem w Gdyni w jednym gmachu z siostrzeńcem komandora Kłossowskiego. Któregoś dnia przekazał mi, że komandor chciałby spotkać się ze mna. Podczas kolejnej delegacji służbowej odwiedziłem Kłossowskiego w jego mieszkaniu w Warszawie. Martwiły go oczywiście posądzenia, że nie przekazał ofiarowanych przedmiotów do adresatów. Z tego, co mówili mu przed wyjazdem z Harbinu członkowie Komitetu Repatriacyjnego, pamiętał jedynie, że tą cenną figurą miała być mongolska wersja chińskiej bogini Guanyin wykopana przez Grochowskiego w ruinach Miasta Czyngis-chana. Z jakiego mogła pochodzić okresu, komandor Kłossowski nie wiedział. Powtórzył natomiast, że zgodnie z życzeniem p. Grochowskiej przekazał posag do Pałacu Prezydenckiego, a prezydentem Rzeczpospolitej Polskiej (jeszcze nie PRL) był wówczas Bolesław Bierut. Żadnych pokwitowań odbioru komandor ze względów oczywistych nie zażądał. 


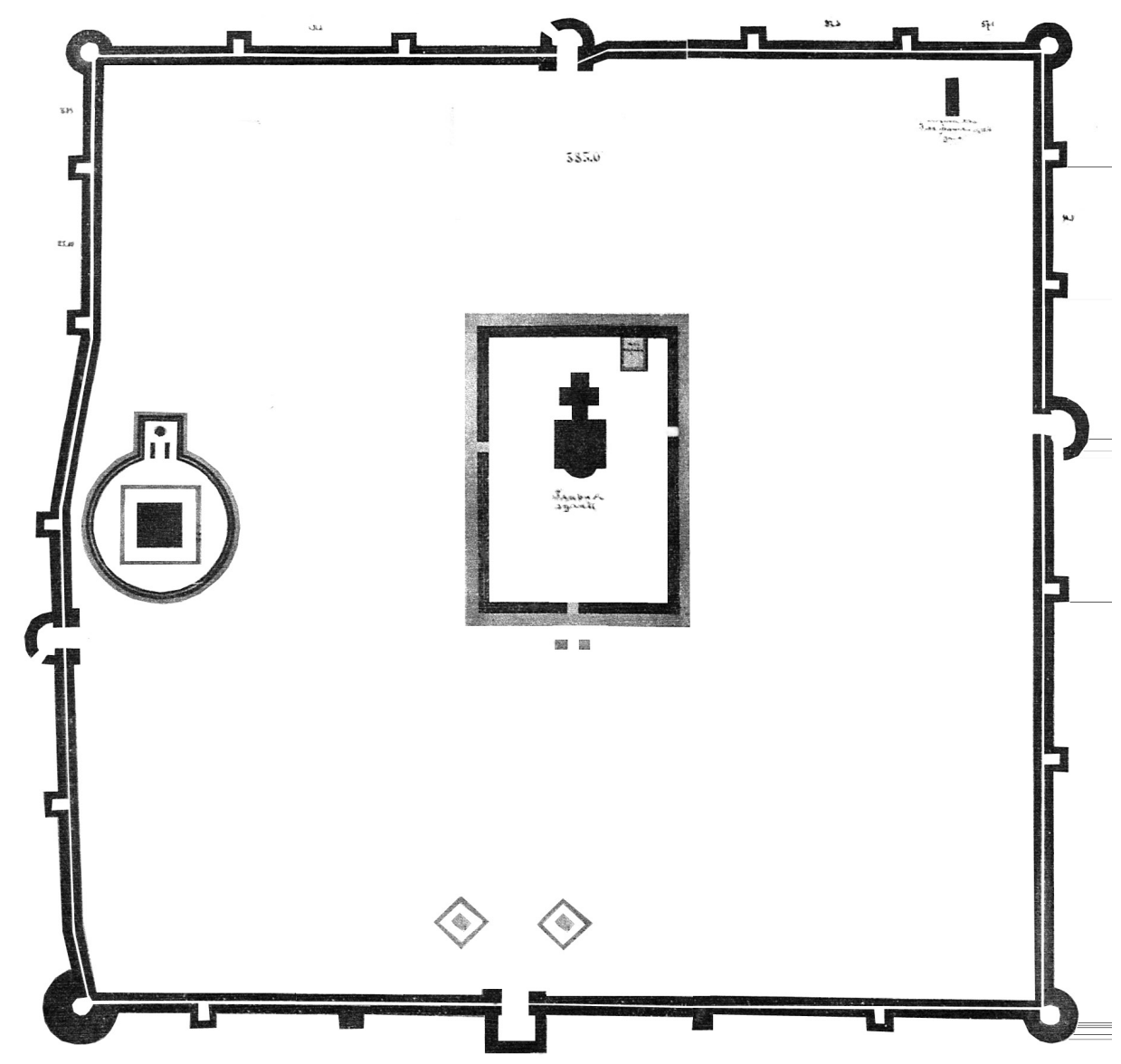

Il. 2. Plan Miasta Czyngis-chana, w którym K. Grochowski wykopał posąg bogini Guanyin Źródło: K. Grochowski, Polacy na Dalekim W schodzie, Harbin 1928. 
Mogę dziś potwierdzić, że faktycznie znacznie później odnalazłem figurę w Muzeum Niepodległości w Warszawie, dokąd po 1989 r. została przekazana z Pałacu Prezydenckiego ${ }^{6}$. Dzięki uprzejmości ówczesnej dyrekcji muzeum uzyskałem kolorowe zdjęcie posagu i mogłem go w końcu zidentyfikować ${ }^{7}$.

Odpowiedź z San Francisco nadeszła szybciej, niż mogłem się spodziewać. Pani Grochowska pisała, że życzeniem jej męża było wprawdzie, aby jego dzienniki znalazły się w Akademii Umiejętności w Krakowie, ale według jej wiedzy powinienem ich szukać w Bibliotece Narodowej w Warszawie. Tam je w końcu znalazłem w ogólnej liczbie 86. W jednym z listów p. Grochowska obszernie informowała mnie o tym, że faktycznie Ungern wyciagnął jej męża z więzienia, a stało się to w następujących okolicznościach. W roku 1917 inżynier Grochowski został zaproszony do wzięcia udziału w organizowanej przez Szwedzką Akademię Nauk ekspedycji naukowej do Urianchaju. Ekspedycja została przerwana ze względu na I wojnę światową i Grochowski wraz z kierownikiem wyprawy profesorem Sederholmem pojechał do Sztokholmu w celu złożenia tam sprawozdania. Na początku 1918 r. wracał Koleja Transsyberyjską do Hajłaru, gdzie wówczas piastował stanowisko dyrektora w oddziale międzynarodowej spółki poszukującej złota na Syberii, w Mongolii i Mandżurii. Podczas postoju pociagu w Czycie został poddany rewizji osobistej przez oddział rezydującego tam atamana Siemionowa. Wyprowadzono go z przedziału, po czym zatrzymano pod zarzutem szpiegostwa na rzecz Niemiec. Znaleziono przy nim bowiem mapy wojskowe opracowane przez Oddział Topograficzny Głównego Sztabu Armii Rosyjskiej, z których korzystał - tak jak w trakcie poprzednich ekspedycji - także w Kraju Urianchajskim. Nie chcąc rozstać się z tak cennymi w jego pracy geologicznej mapami, Grochowski woził je w swoim bagażu osobistym. Do tego doszedł jeszcze budzący podejrzenia Siemionowa fakt, że studiował on na niemieckich uczelniach i przez kilka lat mieszkał w Niemczech. Wszystko to sprawiło, że stawiane zarzuty groziły mu sądem polowym. Zawiadomiona o aresztowaniu męża p. Grochowska zdecydowała się pójść do kwaterującego w Hajłarze barona Ungerna i złożyć na jego ręce prośbę o interwencję. Wbrew przewidywaniom nie tylko udzielił on jej audiencji, lecz osobiście interweniował u Siemionowa, powodując natychmiastowe zwolnienie aresztowanego.

Ungern był zagorzałym monarchistą i tak jak Chińczycy, Japończycy, Mongołowie czy Tybetańczycy uważał, że władza jest dana od Boga (lub pochodzi z woli Niebios). Dlatego każdy, kto chciał ją odebrać monarsze, stawał się groźnym przestępca. Później niejako potwierdził to przekonanie, gdyż niezwłocznie po zdobyciu Urgi przekazał władzę w Mongolii Bogdo Gegenowi, choć z pewnością liczył na to,

${ }^{6}$ O tym, że figura Guanyin została z Pałacu Prezydenckiego usunięta i trafiła do Muzeum Niepodległości, dowiedziałem się, o ile dobrze pamiętam, w roku 1992 od Marka Cabanowskiego, pracującego wówczas w Muzeum Niepodległości

Zdjęcie to zostało opublikowane przy moim artykule pt. Jedwabne Szlaki i insignier Kazimierz, Grochowski, „Gdańskie Studia Azji Wschodniej” 2015, z. 7, na wkładce między stronami 40 i 41. 
że ten zaproponuje mu stanowisko zwierzchnika mongolskich sił zbrojnych. Dążąc do zdobycia władzy w Rosji, również zamierzał oddać ja prawowitemu władcy, za jakiego uważał brata Mikołaja II, księcia Michała Aleksandrowicza, mającego rzekomo ukrywać się na Syberii. Nie taił swoich kontrowersyjnych poglądów dotyczących kultury białej rasy także wówczas, gdy był przesłuchiwany przez bolszewicki trybunał w Troickosawsku:

Nie ma wątpliwości, że Wschód będzie musiał zetknąć się z Zachodem. Kultura białej rasy, która doprowadziła narody europejskie do rewolucji, której towarzyszyła przez wieki powszechna niwelacja, upadek arystokracji etc., podlega rozpadowi i zastapieniu jej przez żółtą, wschodnią kulturę, która narodziła się trzy tysiące lat temu i nadal pozostaje w stanie nienaruszonym ${ }^{8}$.

Czym kierował się Ungern, wstawiając się za nieznanym sobie polskim inżynierem? Pobudki humanitarne były mu chyba zupełnie obce. Można więc domyślać się, że, decydując się na ten gest wspaniałomyślności, miał na uwadze także swoje własne interesy. Dopiero znacznie później, przeglądając dzienniki inżyniera, dowiedziałem się, że baron uzyskał wiadomość o zarekwirowaniu na Syberii przez oddział białych 50 ton platyny. Z Rosji pochodziło $90 \%$ wydobycia tego metalu i tradycyjnie bito z niej monety o najwyższych nominałach. Ungern zdawał sobie sprawę, że, bijąc monety z platyny, uniezależni się finansowo zarówno od trzymających kasę wojskowych, jak i od lądujących we Władywostoku Japończyków. Już po śmierci barona znaleziono jego własnoręczne szkice $z$ awersami i rewersami nigdy niewybitych platynowych pieniędzy. W notatnikach Grochowskiego znalazłem też informację, że Ungern dał mu glejt nietykalności i wysłał w charakterze swego osobistego wysłannika do Czyty. Można się domyślać, że powodem były wątpliwości, czy rzekome tony platyny były rzeczywiście tym cennym kruszcem, który być może Siemionow chciał mu dać na potrzeby jego dywizji zamiast oczekiwanego przez barona złota. Są bowiem w notatnikach Grochowskiego wyraźne wskazówki, że dokonał on z polecenia Ungerna ekspertyzy znajdującego się w Czycie metalu i stwierdził, iż rzekoma platyna była niestety tylko wolframem. A wolfram to metal zbyt twardy, aby móc bić z niego monety. Możliwe też, że Ungern uznał, iż znany w Hajłarze i w całej Mongolii inżynier, mający tak dobre stosunki z mongolskimi książętami nojonami, mający wyłączne prawo do eksploatacji złota na terenie Bargi, może być mu jeszcze do czegoś potrzebny.

Wróćmy jednak do Hajłaru, gdzie Grochowski przebywał do 1922 r., kiedy został zmuszony przenieść się do bezpieczniejszego pod każdym względem w owym czasie Harbinu. W latach 1918 r. Hajłar został zajęty przez oddział wojsk Ungerna, składający się przeważnie z Mongołów (Characzynów) walczących wcześniej pod

8 Cyt. za: L. Józefowicz, Samodierżec pustyni. Fenomen sud'by barona R.F. Ungern-Sternberga, Moskwa 1993, s. 14. 
wodzą księcia Babudżaba z Chińczykami, którzy po jego śmierci wstąpili do ungernowskiej Azjatyckiej Konnej Dywizji. W dywizji było wielu Polaków, m.in. wspomniany Kamil Giżycki oraz pułkownik artylerii Antoni Aleksandrowicz. Ten ostatni zapisał się pozytywnie w historii hajłarskiej Polonii, gdyż na jego prośbę Ungern oddał na użytek Polaków jeden budynek kolejowy na tamtejszy kościół katolicki. Grochowski, który nigdy nie darzył sympatią carskich generałów i przetaczających się przez Hajłar wojsk białogwardyjskich - czemu niejednokrotnie dawał wyraz w swoich zapiskach i publikacjach - zawsze odstępował od tej zasady jedynie w stosunku do barona Ungerna. Określał go jako „bardzo walecznego i wykształconego, a przy tym rycerskiego i honorowego oficera, który jednakowoż odznaczał się niezmiernym okrucieństwem wobec swoich nieprzyjaciół - bolszewików" " Ta dość jednostronna charakterystyka człowieka, któremu nawet jego sprzymierzeńcy w walce z Armią Czerwoną dali przydomek „krwawego barona”, moim zdaniem była spowodowana wdzięcznością za uratowanie go od niechybnej śmierci w czasie podróży przez Czytę do Hajłaru.

W kolejnym liście, jaki otrzymałem od p. Grochowskiej, były dalsze informacje o tym, że powinienem był szukać dzienników i innych dokumentów inżyniera w Bibliotece Narodowej w Warszawie. Tam też je w końcu znalazłem.

Kochany panie! - tak zwracała się do mnie w drugim liście - Bardzo się cieszę Pana zainteresowaniem pracami mojego ś.p. męża. Pyta Pan o jego życiorys naukowy. Muszę tu wyjaśnić, że życzeniem jego było, aby cały dorobek pracy archeologicznej został przekazany ukochanej Ojczyźnie - Polsce.

W dalszej części listu p. Grochowska, która miała już wówczas około 80 lat albo i więcej, napisała:

Moja pamięć nie może ogarnaćć całej pracy mego ś.p. męża, tak, jakby dały panu właśnie te wszystkie, przeszło trzydzieści notesów zapisanych ręką mego męża. To były cenne zapiski i ś.p. mąż życzył sobie, by były one kiedyś w Bibliotece Narodowej w Warszawie (...) Jeżeli Pan specjalnie coś będzie chciał wiedzieć, to bardzo chętnie służę, bo przy zapytaniach odnawia się pamięć. Najwięcej wiadomości uzyska Pan ze wspomnianych już notesów, gdzie znajdzie Pan odbitki i plany grobowców miasta Dżengis-chana i innych odkryć archeologicznych i geologicznych.

Zaprzestałem więc poszukiwań w Krakowie, choć przyniosły już pewne rezultaty w postaci eksponatów przesłanych przez niego do Katedry Antropologii Uniwersytetu Jagiellońskiego (m.in. dwa kompletne szkielety z około XII wieku, a więc z epoki Czyngis-chana z wyposażeniem grobowym) i pojechałem niezwłocznie do Warszawy. Odezwało się we mnie zauważone już przez naszego polonistę Czesła-

9 K. Grochowski, Polacy..., s. 118. 
wa Bobolewskiego zacięcie detektywa-historyka. Na szkolnych wycieczkach byłem zawsze najbardziej dociekliwym tropicielem tajemnic znajdywanych niekiedy po gwałtownych burzach na brzegu Sungari starych monet, brązowej końskiej uprzęży czy grotów strzał. Tym razem zaintrygował mnie plan Miasta Czyngis-chana (kiedyś pisało się Dżengis-chana, jak to jest w liście p. Grochowskiej) z centralnym budynkiem w kształcie nestoriańskiego krzyża. W Bibliotece Narodowej (jeszcze w owym czasie na Rakowieckiej) nikt nie był w stanie udzielić mi odpowiedzi na moje pytania. W kartotekach nie było żadnych śladów istnienia daru p. Grochowskiej. Dopiero, gdy uściśliłem, że chodziło mi o rękopiśmienne dzienniki, uprzejma bibliotekarka rozłożył ręce, wyjaśniając:

- Ależ proszę pana, to wcale nie może być tu. Dział Rękopisów jest na Placu Krasińskich. Tylko dziś już tam pan nie zdąży.

- A mapy?

- Mapy są gdzie indziej. Czasopisma jeszcze w innym miejscu. No, a jeżeli szuka pan jeszcze jakichś dzieł sztuki, to powinien pan iść z tym do Muzeum Narodowego.

Kiedy wróciłem na Wybrzeże, w domu czekała na mnie przesyłka z Warszawy, a w niej plik nowych listów od czytelników i kartka z redakcji „Dookoła Świata". Proponowali mi napisanie kolejnego reportażu z mego pobytu w Chinach, też z dużą dozą sensacji, w tym także o poszukiwaniu przez Grochowskiego śladów Czyngis-chana w Mongolii, ale już bez wątku skarbów barona Ungerna. Miałem go przygotować z wyprzedzeniem, tak aby mógł ukazać się w wielkanocnym numerze. Zgodziłem się i zaproponowałem reportaż o wykopaliskach Grochowskiego w Mieście Czyngis-chana z relacją Marco Polo o wczesnym chrześcijaństwie na badanych przez niego obszarach Mongolii i Mandżurii. Akceptację mojej propozycji otrzymałem natychmiast telegramem. A więc temat uznano za interesujący i zostałem niejako zobligowany do wznowienia poszukiwań. Napisałem kilka kolejnych listów do oddziału Biblioteki Narodowej na Placu Krasińskich, do Muzeum Narodowego, do Wydziału Orientalnego Uniwersytetu Warszawskiego.

Jakież było moje zdziwienie i radość zarazem, gdy po paru tygodniach otrzymałem z Warszawy grubą kopertę z pieczęcią Biblioteki Narodowej i z tak cenną dla mnie zawartością. Do listu przewodniego załączony został obszerny wykaz rękopisów, map oraz książek pochodzących ze zbiorów Grochowskiego. Figurował tam także plan Miasta Czyngis-chana w dużym formacie sporządzony przez Grochowskiego po drugiej ekspedycji z 1924 r. Najważniejsza pozycja w tym wykazie z numerem sygnatury 6074 nosiła tytuł: Drienniki podróży naukowych na Dalekim Wschodzie w latach 1906-1936. Wdowa po inżynierze Grochowskim wspominała o 30 notesach, tymczasem notatników tych, jak później miałem okazję naocznie się przekonać, było łącznie 86. Karton, w którym się znajdowały, nie miał wtedy jeszcze żadnych uwag bibliotekarzy chociażby o treści poszczególnych dzienników, co mogło świadczyć, że nikt przede mną nie interesował się nimi. 
Zawarte w nich wiadomości wykorzystałem potem w dwóch biograficznych książkach o inżynierze Grochowskim: Fort Grochowski (Olsztyn 1982) oraz Dæ̃ienniki syberyjskich podrózy Kažimierza Grochowskiego 1910-1914 (Lublin 1986). Niektóre z tych informacji zamieściłem także w maszynopisie Dlugiego cienia Wielkiego Muru (Warszawa 2005). Swego rodzaju podsumowanie rezultatów moich trwających już 60 lat badań i poszukiwań związanych z postacią Grochowskiego zawarłem w jednym z moich artykułów napisanych do „Gdańskich Studiów Azji Wschodniej”" Myślą przewodnią tej publikacji było zwrócenie uwagę na wciąż niedoceniane zasługi Grochowskiego w dziele poznania historii Bargi (tj. przylegającej do Mandżurii części Wschodniej Mongolii), samej Mandżurii oraz obszarów Południowo-Wschodniej Syberii, które do 1850 r. nominalnie należały do Chin, później zaś były znane jako Kraj Ussuryjski (Kraj Przymorski), Kraj Chabarowski i Obwód Amurski. Był on bowiem jednym z pierwszych europejskich badaczy (i oczywiście pierwszym Polakiem) istniejących kolejno na tych obszarach państw niechińskich - Wei, Bohai, Liao i Złotego Cesarstwa (Jin) oraz przebiegających przez nie wschodnich odnóg Jedwabnych Szlaków znanych obecnie pod nazwą Stepowych Jedwabnych Szlaków.

To właśnie dzięki mającej miejsce w ostatnich latach redefinicji pojęcia Jedwabnego Szlaku (Silk Road Concept reconsideration) w kierunku stosowania liczby mnogiej i uznania terminu Stepowych Jedwabnych Szlaków ${ }^{11}$ stała się obecnie przedmiotem ożywionych dyskusji wśród znawców przedmiotu. Jest to o tyle istotna zmiana, że badania historyczne, geograficzne i archeologiczne dotyczące tych obszarów zaczynają nabierać innego wymiaru, jeżeli będziemy je rozpatrywali w kontekście przeprowadzanych w przeszłości i prowadzonych nadal badań nad Jedwabnym Szlakiem (Jedwabnymi Szlakami). Skoro pojęcie Jedwabny Szlak uległo w ostatnich dziesięcioleciach wspomnianej redefinicji i rozszerzeniu, to możemy teraz mówić o badaniach Grochowskiego jako o badaniach dotyczących jego nieodłącznej części składowej - „Stepowych Jedwabnych Szlaków”. Według mojej wiedzy inżynier Grochowski był pierwszym Europejczykiem, który zwrócił uwagę kręgów naukowych, że jedna z odnóg Jedwabnego Szlaku po dotarciu do Datongu prowadziła na wschód, przez terytorium późniejszej Mandżurii, co zresztą mogłem potwierdzić wieloma jego wypowiedziami ${ }^{12}$.

Z opisu Miasta Czyngis-chana, jaki pozostawił nam Grochowski, wynika, że było ono zbudowane przez naród prowadzący już w pełni osiadły tryb życia, gdyż zostało otoczone kwadratem wysokich murów (o bokach długości 600 m), z dwie-

10 E. Kajdański, Jedwabne Słlaki..., s. 15-40.

11 Stepowymi Jedwabnymi Szlakami nazywane są dziś przeważnie, zarówno w Chinach, jak i na Zachodzie, wschodnie odnogi głównego szlaku prowadzące z Dunhuangu na wschód przez Mongolię Wewnętrzną i dawną Mandżurię do ówczesnych państw tego obszaru oraz do Korei i Japonii.

12 E. Kajdański, Jedwabne Səlaki..., s. 37. 
ma masywnymi bramami w murach zachodnim i wschodnim. Prowadził on swoje wykopaliska głównie w centralnej części miasta, gdzie odkrył m.in. fundamenty otoczonego wewnętrznym murem pałacu lub też świątyni oraz kamienny fundament innej okragłej budowli bliżej zachodniego muru zewnętrznego.

Przednia część pałacu - zanotował - kwadratowa o bokach 26,1 na 26,1 metra. Tylna, tj. na północ zwrócona część, zbudowana w kształcie krzyża. Szczegół ten nasuwa różne przypuszczenia, które jednakowoż aż do czasu dokładniejszych poszukiwań archeologicznych nie mogą być omawiane ${ }^{13}$.

Miałem możliwość dowiedzieć się, co Grochowski miał tu na myśli, od Gwidona Sadkowskiego po ukazaniu się mojego reportażu w 1958 r., o czym wspominałem w moich ówczesnych publikacjach ${ }^{14}$. Był on bliski przekonania, że odnalazł stolicę Kapłana Jana, chrześcijańskiego władcy Kereitów, znanego chińskim historykom pod imieniem Wang-chan, o którym pisał w swych wspomnieniach Marco Polo. Wang-chan miał zostać pokonany w bitwie z Czyngis-chanem, lecz jego chrześcijańscy potomkowie jeszcze przez długie lata zamieszkiwali i panowali w jakiejś części dawnego królestwa Tenduk. Wykopany przez Grochowskiego w Mieście Czyngis-chana posag bogini miłosierdzia Guanyin mógł jego zdaniem być jej wersją chrześcijańską.

Przyjąłem w swoich publikacjach punkt widzenia Grochowskiego, lecz z biegiem czasu pojawiły się także wątpliwości. Istotnymi bowiem dowodami przy datowaniu okresu powstania i istnienia Miasta Czyngis-chana są znalezione przez niego w czasie wykopalisk monety. Najstarsze z nich pochodziły z okresu chińskiej dynastii Tang, a ściślej z lat panowania cesarza Gaozu (618-649) ${ }^{15}$. „Najmłodsze czy też najświeższe monety - pisze dalej Grochowski - pochodziły z czasów (tatarskiej) dynastii Liao i były bite przy cesarzu Szy-czun [Shizong - E.K.] w 1188 r. po Chr." ${ }^{16}$. Tu znalazłem błąd. Grochowski korzystał bowiem z popularnego w Mandżurii katalogu chińskich monet Lockharta ${ }^{17}$, w którym data 1188 została podana błędnie. Zgodnie z nowszymi katalogami i publikacjami historycznymi panowanie cesarza Shizonga z dynastii Liao przypada na lata 847-950, zatem różnica jest spora - ponad dwieście lat.

13 K. Grochowski, Polacy..., s. 124.

14 E. Kajdański, Tajemnica „Miasta Díengis-chana” (tak wymagała ówczesna pisownia), „Wiedza i Życie” 1959, nr 10; idem, Kim byt keól Tenduk - Kapłan Jan?, „Dziennik Bałtycki” („Rejsy”), 15.05.1960.

15 W państwie Bohai, powstałym w tym czasie na terenie Mandżurii i pozostającym w wasalnej zależności od Chin, monety chińskie były pieniądzem obiegowym. Także w cesarstwie Liao chińskie monety były w obiegu na równi z własnymi.

16 K. Grochowski, Polacy...

17 The Stewart Lockhart Colection of Chinese Copper Coins, Royal Asiatic Society, North China Branch, Shanghai 1915. 
Opublikowany w zeszycie 4 GSAW artykuł pozwoliłem sobie zakończyć moja własną ekspertyza posagu Guanyin wykopanego przez Grochowskiego w Mieście Czyngis-chana. Zacznę od tego, że Kitanowie, będący w przeszłości szamanistami, niedługo przed stworzeniem cesarstwa Liao przejęli ezoteryczny buddyzm bezpośrednio z Tybetu, gdzie uzyskał on status religii państwowej w roku 755. Zgodnie z opinią japońskiego badacza historii Liao - Ryuzo Torii, który prowadził wykopaliska na obszarze Mandżurii i Bargi mniej więcej w tym samym czasie co Grochowski, część Kitanów wyznawała chrześcijaństwo nestoriańskie ${ }^{18}$. Jakkolwiek wcześniejsi europejscy badacze nie wykluczali, że postać Gyanyin narodziła się w Chinach pod wpływem rozpowszechniającego się tam chrześcijaństwa nestoriańskiego, to jednak pytanie, którędy i kiedy, długo pozostawało bez odpowiedzi. Problem polegał na tym, że w panteonie buddyjskim, jaki Chiny przejeły z Indii, nie było żadnego żeńskiego bóstwa odpowiadającego postaci Guanyin. Najbardziej popularnym „miłosiernym” bodhisatwą był Avalokiteswara, który na przestrzeni wieków „,przemienił się” w Chinach (a w konsekwencji także w Korei i Japonii) w bóstwo kobiece - Guanyin.

Według wcześniejszych autorów nastapiło to nie wcześniej niż za panowania dynastii Song. Znany brytyjski sinolog i dyplomata Herbert Giles (1845-1935) uważał, że w Chinach „aż do połowy XII wieku Guanyin była przedstawiana jako mężczyzna”"19. Późniejsi autorzy przesuwali tę datę na wcześniejsze i w latach 20. XX wieku znany rosyjski (a później sowiecki) badacz życia duchowego w Chinach Wasili Aleksiejew cofnął datę przeobrażenia się Avalokiteswary w bóstwo żeńskie na połowę VI wieku ${ }^{20}$. W moim przekonaniu jego opinia znacznie przybliża nas do czasu rzeczywistego, co starałem się udokumentować w jednej z moich publikacji ${ }^{21}$. Stało się to bowiem dzięki istnieniu Stepowych Jedwabnych Szlaków i rozwojowi obszarów, przez które te szlaki przebiegały. W tym artykule zwracałem uwagę m.in. na wiele podobieństw w przedstawianiu sylwetek kobiet i ich ubioru przez artystów z czasów dynastii Wei w Chinach północnych, Japonii i Korei. Nie mogło to być dziełem przypadku. Jak bowiem wytłumaczyć, że już na przestrzeni V-VII wieku żeńskie wizerunki Guanyin w Chinach północnych, Korei i Japonii miały aż tyle wspólnych szczegółów (np. takich, jak omówione niżej ,jaskółcze ogony” na szalach widocznych na posagach Guanyin z początków VII wieku w Japonii: Yumedono Kwannon i Kudara Kwannon w Nara ${ }^{22}$.

18 R. Torii, Sculptured Stone Tombs of the Liao Dynasty, Harvard-Yenching Institute, Peking 1942. Torii wykopał kilka metalowych i kamiennych krzyży nestoriańskich oraz kielich mszalny i był przekonany, że na jednej z rzeźb znajdowała się scena przedstawiająca Jezusa w kołysce (s. 59). Grochowski także przychylał się do uznania głównego budynku w kształcie krzyża na planie Miasta Czyngis-chana za przejaw symboliki chrześcijańskiej.

19 Cyt. za: C.A.S. Williams, Chinese Symbolism and Art Motives, Singapore 2006, s. 242.

20 W.A. Aleksiejew, Kitajskaja narodnaja kartina, Moskwa 1965, s. 162.

21 E. Kajdański, Guanyin Goddess: Two Bronze Figures - Two Different Stories, „Art of the Orient” 2014, vol. 1, s. 25-40.

22 H.E. Lee, A History of Fsr Eastern Art, New York 1973, s. 150, 151. 
Kontynuując sprawę figury znalezionej przez Grochowskiego, należy zauważyć, że typowe dla tej szkoły buddyzmu są wielorękie i wielogłowe posagi bodhisatwów ${ }^{23}$ i brązowa Guanyin została wykonana zgodnie z tymi tradycjami ezoterycznego buddyzmu. Należy do tzw. jedenastogłowych Guanyin, co zostało uwidocznione w koronie z masek wokół jej głowy ${ }^{24}$. Trzyma ona nieduży rytualny dzbanek z gałązką wierzby w lewej ręce ${ }^{25} \mathrm{i}$ buddyjski różaniec w prawej. Smukłe ciało bogini okrywa obcisła szata o wąskich rękawach. Dodatkową ozdobą jest potrójny naszyjnik z drogich kamieni (najbardziej rozpowszechnione w naszyjnikach zdobiących uroczyste ubiory kobiece były w cesarstwie Liao, podobnie jak w Tybecie i Mongolii, korale, turkusy, perły oraz bursztyn ${ }^{26}$. Podobne trzy sznury kamieni szlachetnych zdobią dolną część szaty na wysokości kolan. Przez jej ramiona przerzucony jest bardzo charakterystyczny rodzaj szala, właściwie pasa (chiń. piaodaizi, ang. flying belt - „fruwający pas”). Jest to bardzo istotny szczegół dla identyfikacji i datowania figury, gdyż ten atrybut ubioru pojawił się i stał się modny w północnych Chinach już na dworze cesarza Dao Wudi (386-408) z dynastii Wei założonej po zjednoczeniu plemion sianbijskich Toba, uznawanych przez niektórych autorów za przodków Kitanów ${ }^{27}$.

Moda ta ulegała zmianom, a jedna z nich było pojawienie się, przypuszczalnie już na początku $\mathrm{V}$ wieku, rozdwojonych końcówek piaodaiz̨i, nazywanych jianjiao yanwei (,jaskółcze ogony z ostrymi zakończeniami”, ang. swallow-tails with sharp edges $)^{28}$. Brązowe bóstwo stoi boso na podstawie przedstawiającej ośmiopłatkowy kwiat lotosu, zdobiący zwykle piedestały buddyjskich bodhisatwów. Takie piedestały, a konkretnie ich kształt, liczba płatków kwiatu lotosu i ich ułożenie, są uznawane za niezwykle pomocne przy datowaniu figur buddyjskich bóstw. Te szczegóły także zostały uwzględnione w niniejszej ekspertyzie. Podstawa składa się z trzech części: górna jest typowym wczesnym tronem w kształcie kwiatu lotosu, liczącym na dwóch poziomach szesnaście płatków zwróconych ku górze, środkowa część ma stylizowane płatki (lub liście, jak przypuszczają niektórzy badacze), natomiast dolny podobny jest do ośmiobocznej komory grobowej Kitanów, którą

\footnotetext{
23 The Art of East Asia, ed. G. Fahr-Becker, vol. 1, Cologne 1999, s. 179.

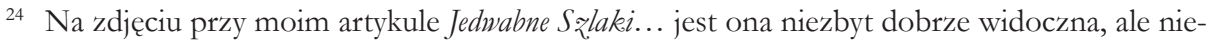
stety nie miałem zgody na wykonanie własnych zdjęć ani na obejrzenie oryginalnego obiektu.

${ }_{25}$ Nosi on chińską nazwę guanyinzun („,naczynie Guanyin”). Zwykle jest to rodzaj wazonika z gałązka, lecz w tradycji Kitanów postać ta jest także przedstawiana z tzw. dzbanem z kogucim grzebieniem. Takie dzbany z białej, żółtej i zielonej ceramiki były znajdywane bardzo często w grobowcach Kitanów. Zob. A. Kajdańska, E. Kajdański, Jedwab. Sqlakami dżonek i karawan, wyd. 2, Warszawa 2017, s. 375.

26 Jak wykazały badania, także ten sprowadzany z wybrzeży Bałtyku.

27 Hua Mei, Zhongguo Fuzhuanfu (Historia chińskiego ubioru), Pekin 1988, s. 27, 28; E. Kajdański, Jedwabne Sqlaki..., s. 20, 21.

28 Hua Mei, Zhongguo Fužbuanfu...
} 
opisał Ryuzo Torii ${ }^{29}$. Torii zwraca także uwagę na fakt, że tradycyjne kształty komór grobowych Kitanów ściśle odwzorowywały kształty wczesnych mongolskich i tureckich jurt ${ }^{30}$. Na dolnej podstawie widzimy osiem poziomych wydłużonych nisz, uzyskanych w procesie przygotowań do dokonania odlewu z czterema parami zwróconych ku sobie smoków, co zdaniem wspomnianego badacza jest raczej niezwykłe w konstrukcji buddyjskich tronów lotosowych.

Posag Guanyin odkopany przez Grochowskiego jest pozłacany, jednakże jego cyzelowanie i przygotowanie grawerskie przed nałożeniem złota raczej nie dorównuje dziełom najwyższej klasy rzemieślników, jakie miałem okazję oglądać podczas moich pobytów w Azji. Być może został on wykonany w warsztacie klasztornym prowadzonym przez mnichów lub też jego autorem jest chiński artysta pozostający na terenach podbitych przez Kitanów ${ }^{31}$.

Zachowało się bardzo niewiele dzieł sztuki brązowniczej Kitanów, być może dlatego, że do II wojny światowej europejscy badacze nie interesowali się sztuką cesarstwa Liao i przeważnie nie odróżniali tych dzieł od chińskich. Natomiast chińscy archeologowie zwrócili na nie większą uwagę dopiero po rewolucji kulturalnej, gdy w roku $1986 \mathrm{w}$ prowincji Jilin odkryto nienaruszony grobowiec księżniczki Chenguo, wnuczki cesarza Jingzonga (969-982) z dynastii Liao i jej męża. Znalezione w nim przedmioty przykuły uwagę znawców Dalekiego Wschodu na całym świecie, nie tylko ze względu na obfitość cennych kosztowności ze srebra i złota, nie wyłączając srebrnych butów czy złotych koron, ale też przedmiotów świadczących o przynależności pochowanych do innej kultury i stylu życia niż na przykład na sąsiadujących obszarach Chin. Postacie te miały powyjmowane wnętrzności, były zmumifikowane, miały złote maski na twarzach i wierzchnie ubiory ze srebrnej siatki ${ }^{32}$. Drugi grobowiec należący do członka rodziny cesarskiej Liao odkryto w roku $2002 \mathrm{w}$ Mongolii Wewnętrznej ${ }^{33}$. Po tym, jak ujawniono publicznie, że znalezisko pochodziło z okresu dynastii Liao, wydawana w Pekinie anglojęzyczna gazeta skomentowała to wydarzenie następująco: „Panowali oni [Kitanowie - E.K.] przez 209 lat nad rozległymi terytoriami w północnych Chinach, lecz pozostawili po sobie niewiele zabytków, które zachowały się do czasów współczesnych" ${ }^{34}$.

Zainteresowanie tymi odkryciami w świecie zaowocowało kilkoma wystawami zagranicznymi dzieł sztuki odkrytych w Chinach, jak również pochodzących

29 R. Torii, Sculptured Stone Tombs..., s. 3-10.

30 Ibidem, s. 8, 96.

31 Pod władzą Kitanów znajdowało się wiele miast o dłuższych tradycjach odlewnictwa brązu, m.in. Youzhou, czyli dzisiejszy Pekin.

32 A. Kajdańska, E. Kajdański, Jedwab..., s. 376, 377.

33 Obydwa te znaleziska pochodziły z obszarów należących w czasach Grochowskiego do ówczesnej Mandżurii oraz Bargi.

34 The Kingdom of Khitans; Sudden Rise, Sudden Fall, „China Daily”, 19.06.2003. 
z wcześniejszych wykopalisk rozproszonych po różnych muzeach w USA, Japonii i Europie. Pierwsza wystawa sztuki Kitanów została zorganizowana w okresie od października do grudnia 2006 r. przez amerykańskie Asiatic Society we współpracy z odpowiednimi władzami autonomicznego regionu Mongolii Wewnętrznej (Inner Mongolia Autonomous Region Historic Relics Archeological Studies Research). Złożyło się na nią dwieście eksponatów, przeważnie z wykopalisk z 2002 r. Twórcy wystawy zwracali uwagę, że chińscy uczeni jeszcze w połowie XX wieku nie doceniali osiagnięć w dziedzinach gospodarki i handlu oraz nauki, kultury i sztuki Kitanów, choć ci panowali na rozległych terenach Mongolii, Mandżurii i północnych Chin. Skutecznie rywalizowali przy tym z innymi mocarstwami ówczesnej Azji, jak Chiny Songów, cesarstwo Khmerów czy cesarstwo Abbasydów w Iranie i Iraku. Zdaniem organizatora wystawy, dr. Adriana Prosera eksponowane obiekty odzwierciedlały życie i praktyki nomadów, którzy po przyjęciu osiadłego trybu życia utrzymywali zróżnicowane tradycje kulturalne, rozwijając jednocześnie różnorakie więzi społeczne, polityczne i handlowe z pozostałą częścią Azji, łącznie z Persja, Korea, Japonią i Chinami Songów. W następnej kolejności wystawy te były eksponowane w Muzeum Sztuki Wschodniej w Kolonii i w Rietberg Museum w Zurichu. W 2012 r. podobną wystawę, ale bazującą głównie na eksponatach pochodzących z wykopaliska w Liaoningu, zorganizowało University Art Museum w Tokio.

$\mathrm{Na}$ koniec jeszcze jeden argument, który mam nadzieję przekona także tych nadal nieprzekonanych o słuszności tego, co napisałem wyżej. Czasami zdarza się, że przez tzw. złośliwość rzeczy martwych, mając pod ręką potwierdzenie nurtującej nas informacji, przez lata jej nie potrafimy znaleźć. Mi się także to przytrafiło, gdy próbowałem rozwiać wattpliwości związane z pochodzeniem i wiekiem figury Guanyin z wykopalisk Grochowskiego. Na moim regale z książkami, przy którym codziennie siadałem, stoi już od 30 lat sowiecka encyklopedia mitów, do której często sięgałem, lecz na interesującą mnie informację natrafiłem dopiero zupełnie niedawno ${ }^{35}$. Zostało w niej zamieszczone zdjęcie bardzo podobnej, niemalże identycznej pod każdym względem figury Guanyin z informacją, że przedstawiała „Rzeźbę Guanyin, odlew brązowy, złocony, z XI wieku”, znajdującą się w Muzeum Sztuki Narodów Wschodu w Moskwie. Mogłem oczywiście pisać do muzeum z prośbą o więcej szczegółów lecz poprzestałem wtedy na analizie zdjęcia, które było lepszej jakości i zawierało więcej czytelnych szczegółów niż to, które otrzymałem z Muzeum Niepodległości.

35 Hasło: Guanyin [w:] Mify narodow mira. Enciktopedija w dwuch tomach, t. 1, red. S.A. Tokariew, Moskwa 1987, s. 338, 339. 


\section{SUMMARY}

\section{KAZIMIERZ GROCHOWSKI AND THE GUANYIN GODDESS; FROM REPORTAGE TO EXPERT ASSESSMENT}

This article is an attempt to sum up the results of many years of interest in the scholarly activity in the Far East of the engineer Kazimierz Grochowski. For thirty years (1906-1937), he carried out geological, archaeological, and ethnographic research in Eastern Siberia, Barga and Manchuria. He was also principal of my high-school in Harbin, where I was born and spent my childhood and youth. He was co-founder of the international Manchuria Research Society and of the museum with its rich range of collections that is now the state Museum of Heilonjiang Province. Here he transferred most of the objects from his excavations, including silver Roman coins (beginning from the rule of the Emperor Hadrian [117-138 AD]). They were discovered by Grochowski on an escarpment in the centre of today's Harbin, where - he believed - there had been a ford over the river and an inn for merchants. By 1928, Grochowski was convinced that Harbin was located at a spot through which the trade route ran linking the Roman East with Korea and Japan. Today this has been confirmed by the existence of the so-called Grassland Silk Roads leading from Datong inter alia through Harbin to the East and to the lands on the Pacific.

I began with an adventurous piece of reportage for a magazine for young readers. This quickly took me onto the track of Grochowski's forgotten manuscript journals in the National Library in Warsaw. On the basis of these, I wrote two books about engineer Grochowski. Currently, I am ending this research with an expert assessment of the statue of the Guanyin Goddess excavated by Grochowski. My judgment indicates that it comes from the eleventh century, from the period in these parts of the rule of the non-Chinese Liao dynasty. 